\title{
FINANCIAL ACCESSIBILITY IN COST-SHARING POLICIES IN HIGHER EDUCATION IN MOZAMBIQUE
}

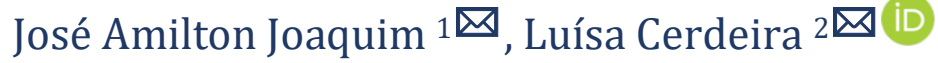 \\ ${ }^{1} \mathrm{MSc}$, Lecturer in the category of Assistant at Eduardo Mondlane University - UEM at the Higher \\ School of Business and Entrepreneurship of Chibuto - ESNEC-Mozambique \\ ${ }^{2}$ Assistant Professor at the Education Institute of the University of Lisbon-Portugal
}

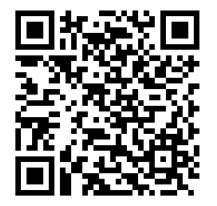

DOI: https://doi.org/10.29121/granthaalayah.v8.i9.2020.1403

Article Type: Research Article

Article Citation: José Amilton Joaquim, and Luísa Cerdeira. (2020). FINANCIAL ACCESSIBILITY IN COST-SHARING POLICIES IN HIGHER EDUCATION IN MOZAMBIQUE. International Journal of Research GRANTHAALAYAH, 8(9), 71-86. https://doi.org/10.29121/granthaa layah.v8.i9.2020.1403

Received Date: 04 September 2020

Accepted Date: 26 September 2020

Keywords:

Higher Education Accessibility

Cost-Sharing Policies

Students' Socio-Economic Features

Study Costs

Living Costs

\section{ABSTRACT}

The massive growth of the student population in higher education institutions has challenged traditional forms of public funding, and costsharing policies have been one of the options used by governments. In this sharing, it is important that, depending on the social and economic characteristics of students, issues related to equity and accessibility are safeguarded. This study seeks to understand how cost-sharing policies taking into account the direct costs of attending higher education, indirect costs, other living expenses and the Mozambicans' social and economic features - can help or hamper the access to higher education in Mozambique. The selected empirical research contexts encompass eight higher education institutions in the province of Gaza - universities and polytechnics - from the public and private sectors. Empirical data were collected from a questionnaire implemented with higher education students; furthermore, the authors carried out a document analysis on the financing of higher education in Mozambique and worldwide. Allows concluding that, in Mozambique, the cost-sharing model follows a dualtrack policy. Also, the part of the financing still ensured by the State is far from meeting the real needs of students and families, due to the high study and living costs, which are well above the students/families' income. There is no diversification of social support for students, and the only help students have comes from scholarships, whose allocation process is inefficient. This calls into question the issues of higher education equity and accessibility, especially for families with the lowest socio-economic conditions in the country.

\section{INTRODUCTION}

At the beginning of the $21^{\text {st }}$ century, higher education (HE) has become increasingly important, both for highly industrialised and developing countries. It is regarded as a basis for democratic civil societies, an engine of economic growth and a policy instrument for the improvement of individual economic mobility and social justice (Johnstone, 2005).

In Mozambique, the concern with HE access and equity derives from the period when the country gained independence in 1975, with the creation of the National Education System, which intended to reverse all the exclusion policies that Mozambicans were subject to in the colonial period.

(C) 2020 The Author(s). This is an open access article distributed under the terms of the Creative Commons Attribution License, which permits unrestricted use, distribution, and reproduction in any medium, provided the original author and source are credited. 
The summary of the law that provided the general guidelines of education, Law 4/83 of the National Education System (NES) (1983) states that "The National Education System ensures access for workers, peasants and their children to all educational levels, and allows the appropriation of science, technique and culture by the working classes" (p. 13).

Up to the present day, according to information from the National Directorate of Higher Education (2018), HE access is one of the mainstays of HE development, in addition to expansion and quality.

Financing is one of the important mechanisms in defining the HE results in the dimensions related to quality, efficiency, access, equity and responsiveness of the education system itself.

The Mozambican State is the largest financier of public higher education institutions (HEIs), and the participation of students/families seems to be very low. As Fonteyne and Jongbloed (2018) sustain, "the current financing mechanism in Mozambique remains based, to a large extent, on the direct financing of public HEIs by the State budget, with minimal cost-sharing by the student" (p. 24). However, private HEIs tend to offer more profitable low-cost programmes.

Still, there is the need to understand that the costs-sharing for HE access by students and families is not restricted only to the study costs, but also to other latent costs, which we can call living or subsistence costs.

According to Cerdeira (2008), citing Usher and Cervenan (2005), the indicators of capacity to finance studies are embodied in the following total costs: Education or Study Costs (tuition fees, including enrolment and course fees, books and school supplies); Living or Maintenance Costs (accommodation, food and others); and Social Support, via scholarships.

Thus, this study seeks to understand the extent to which the cost-sharing policy in Mozambique allows HE students to have accessibility and equity, taking into account both the students' socio-economic features and the costs that they have - both direct costs (HE attendance) and indirect costs (other living expenses).

\section{LITERATURE REVIEW}

History has shown that the State has always been, and continues to be, the guardian of the basic social sectors, such as education in general at the global level, fulfilling its obligation to provide public services that contribute to reducing asymmetries.

Chevaillier and Eicher (2002) recall that more than 30 years ago, in the 1980s, there was a clear distinction between countries where HEIs charged substantial tuition fees and those that applied the principle of free HE.

The past twenty years have witnessed major shifts in the way HE is financed in many countries, both in industrialised and developing countries. These changes result from the challenges faced by governments worldwide that aim to reform the HE financing in response to both pressures, that is, increased demand and severely limited public budgets (Johnstone, 2001, 2005, 2010, 2014; Tekleselassie \& Johnstone, 2004; Woodhall, 2007; Barr, 2007; Marcucci \& Johnstone, 2007; Vossensteyn \& Jong, 2006; Hauptman, 2007; Cerdeira, 2008).

In response to these challenges, according to Johnstone (2010), the HE systems around the world are using nongovernmental or private revenues for the continuous support of HEIs, based on cost-sharing. This support emerges in the form of tuition fees (covering part of the tuition costs) or other charges in countries where the tuition fee for HE was previously free, changes in student support systems, and a shift to student loans to complement or replace the subsidies.

Johnstone (2004) regards cost-sharing - referring to HE in all countries and all situations - as having the contribution of four main actors: (1) the government/taxpayers; (2) parents; (3) students; and/or (4) individual or institutional sponsors.

Hauptman (2007) shows that there is a high variation between countries in terms of the proportion of public and private resources for $\mathrm{HE}$,

In most countries, institutions are financed mainly through public resources, in the form of government support; enrolment rates and other private support sources are low or non-existent. At the other end of the spectrum are countries such as the United States, where private resources make up half or more of the total resources ascribed to higher education (p. 87).

As can be seen in Figure 1 below, in addition to the United States with higher private investment, there are countries such as Australia, England, Japan, Korea and Chile. 
José Amilton Joaquim, and Luísa Cerdeira

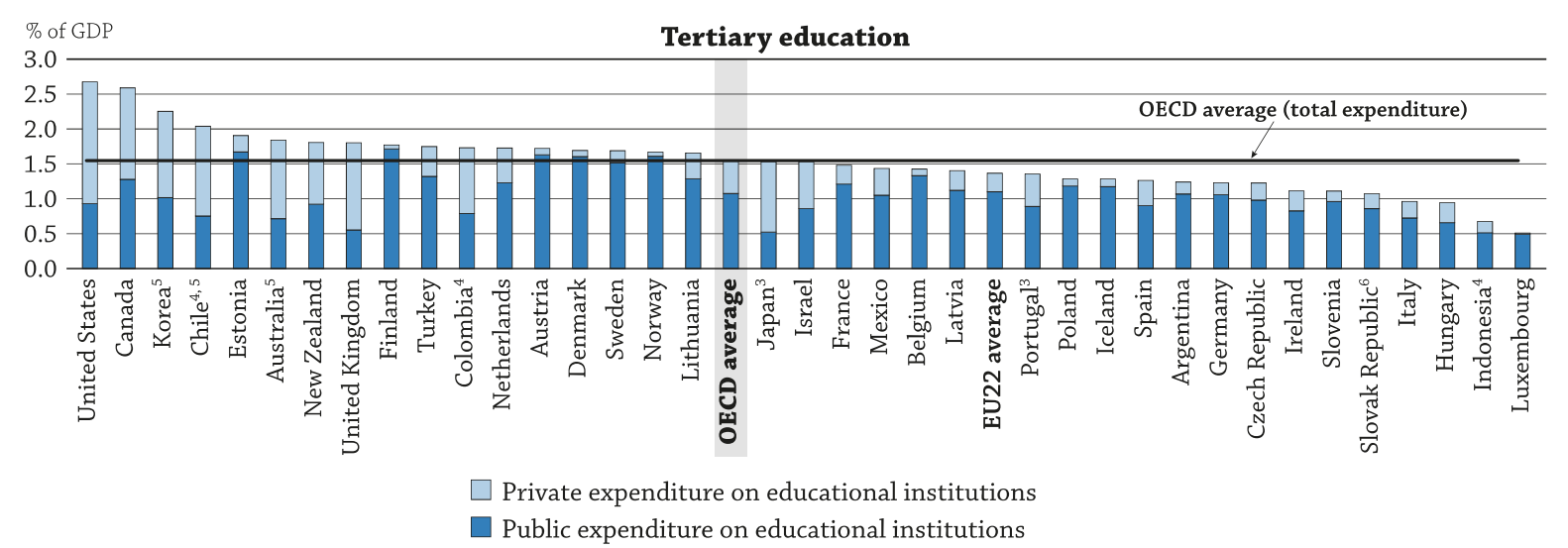

Figure 1: Total public and private expenditure on HE as a percentage of GDP in 2014

Source: OECD (2017, p. 183).

Due to this reality, Zeleza (2016), when analysing governments and popular attitudes towards cost-sharing, acknowledges that, in general, cost-sharing tended to be more accepted in countries that adopted aggressive forms of free-market capitalism. These countries had a private education sector and high enrolment rates, as opposed to countries linked to welfare state policies, where the HE sector was predominantly public or where the enrolment rates were low.

For Cabrito (2004, p. 980), differentiating the financing sources is, for HEIs, the last "commandment" of liberal governments and means seeking funds beyond the public ones, whether through the sale/provision of services, "market-oriented" research or increased student contributions.

This perspective, which tends to make students more accountable for HE costs, received the influence of the human capital theory developed by Schultz (1961) and pursued by Backer (1993).

The human capital theory is based on the foundation, according to Eicher (1998), that education is an investment in the human being, which increase their productivity and, consequently, their earnings.

This rational, which has greatly influenced HE financing, raises several questions about the cost-sharing policy - which, in many countries, represents a cost burden for students and their families - and what this means in terms of HE access. Johnstone (2014) states that tuition fees charged by HEIs are not adequate in having into account the means and the capacity of the families to pay them.

Moreover, according to Zeleza (2016), albeit paramount, tuition fees are only one of the critical points of the costs of attending HE. There are other costs, notably the subsistence expenses, which may be higher than tuition fees.

This leads Ogachi (2011), in an analysis of the new financing trends in the African context, to conclude that, before the 1990s, the threats to academic freedom were characterised by State censorship of teaching and learning processes in the institutions. With the beginning of neoliberal practices in the institutions, from the 1990s onwards, the State as a threat to academic freedom and institutional autonomy in Africa was replaced by the market.

Nicolas Barr (2005) argues that there seems to be a consensus on two fundamental objectives in the HE financing: (i) the concern with quality and diversity, as ends in themselves and as factors that add to the national economy; and (ii) better access for equity and efficiency reasons. If public funds do not suffice, private financing should be encouraged, but care must be taken not to leave out students from unprivileged backgrounds.

Woodhall (2004, p. 39) shares this perspective when she states that just as cost-sharing is an "imperative" for several governments, it must also be an imperative for governments to design and implement equitable and effective support systems for students, to help those who would otherwise be denied access to HE on the grounds of poverty and financial need.

Reality has demonstrated (Vossensteyn, 2009) that cost-sharing also "takes place [...] through a reduction of subsidies to students and their families. Students today must rely more heavily on student loans or own resources rather than on grants and scholarships" (p. 177).

Scholarships have been a classic form of student support, which has been complemented by loans to university students.

According to Chevaillier and Paul (2008), loans are considered a form of public support when they are available to students in special terms, which are possible thanks to some public or private subsidies. 
All this joint effort, ranging from governmental to non-governmental institutions, in social support for students, seeks, in general, to create the conditions for a HE socially fairer, based on HE access and equity, to counter and avoid social exclusion.

Cerdeira (2008) shows that, in addition to HE accessibility, there is the issue of access equity, which is a central issue in the definition of financing policies, and the notion of accessibility does not provide, per se, the information about whether students face or do not face financial barriers to HE attendance.

Thus, according to the author, another concept arises that has to do with the students' ability to finance their studies, which we can call economic accessibility, that is, the circumstance of the students having the necessary resources to be able to study in HE (Cerdeira, 2008). This preliminary understanding of the economic/financial accessibility is, according to Hill, Winston and Boyd (2004), judged by the net price that students pay for a year of attendance at a $\mathrm{HEI}$ in relation to the family income.

However, despite this preliminary understanding, the same authors acknowledge that sometimes it is highly misleading because a student with financial support based on needs will not pay the same price. So, there is an urgent need to compare the data regarding the amount that each student actually pays and the financial resources from social support with the family income (Hill et al., 2004).

Johnstone (2005) argues that this type of research, which uses econometric analyses to support the conventional wisdom that the net price - that is, the combined effect of tuition discounted by the financial support , has little effect on middle and middle-high income students.

Thus, the author advises that research that links cost-sharing and accessibility should examine the effect of higher costs of education passed on to students and families (probably in the form of higher tuition fees, the implementation of tuition fees where they did not previously exist, or the reduction of school grants for student livelihood). The decision to apply for and enrol in any higher education institution; the decision to apply for or enrol in a specific form (for example, a university or a non-university) or a specific program (for example, medicine, law, engineering or the humanities); the likelihood of concluding a degree; the likelihood of progressing to more advanced (and more prestigious and/or remunerative) higher education levels.

Studies on the costs of Portuguese HE students, CESTES I, used two methods to analyse financial barriers to education. The first consisted of comparing the students' costs with the country's Gross Domestic Product (GDP) or the national income. The second methodology compared the students' expenses with the median of the income, which corresponds to the value that records the most cases in the country (Cerdeira, Cabrito, Patrocínio, Machado, \& Brites, 2014). The study highlights that the latter methodology has been used since 2008 by OECD (Organisation for Economic Co-operation and Development).

\section{METHODOLOGY}

This study was carried out in Mozambique, in the province of Gaza. This province has 10 HEIs, which make up $19 \%$ of the total HEIs in Mozambique. Of these, three are public and seven are private. HEIs in the province of Gaza are binary (universities and polytechnics) and have different financing policies, even in public HEIs.

The empirical research, which was carried out in the months of February and March 2018, involved the participation of eight HEIs, three of which are public and five are private.

The questionnaire allowed to obtain information from students about their opinion on HE financing in Mozambique, as well as their socio-economic features. These data were complemented with information from analyses of official documents and academic works (strategic plan, legislation on HE, information on the HEIs' budget, reports and statistics on scholarships and theses, as well as articles and manuals on HE and financing in Mozambique and the world), which made it possible to understand the cost-sharing policies in force in Mozambique.

The questionnaire survey model used in this research has been used in international studies on cost-sharing, as is the case of the project CESTES - Cost of the Student in Higher Education in Portugal (CESTES I in 2010/11; CESTES II in 2015/2016). To note that this survey model underwent an a priori validation process to adapt to the context of the Mozambican reality.

Based on the stratified probabilistic sampling method, 607 students from the three regions of the country, North, Centre and South, were interviewed, with the highest number (83\%) belonging to the Gaza province, where the field research was carried out. Of the students surveyed as per the sample, $53.8 \%$ (the highest percentage) are 
female, and $46.2 \%$ are male. Regarding the students' age, the highest number of students (71.7\%) are between 21 and 30 years old, whereas $28.3 \%$ of students are over 30 years old.

\section{RESEARCH RESULTS AND DISCUSSION}

\subsection{HIGHER EDUCATION COST-SHARING POLICIES IN MOZAMBIQUE}

The historical and political contexts that Mozambique experienced since the socialist policies were characterised by a more centralised economy in the period leading up to the country's independence, in 1975, and the subsequent shift to a more decentralised political regime from the 1980s onwards. They had implications for HE policies in general and financing issues in particular. In the first phase of the socialist period, there was a purely public financing policy, and later, with the democratisation of HE, the system moves to a mixed policy in the public and private HE financing, as can be seen in Figure 2, taken from the 2012-2020 strategic plan, which portrays the current HE financing model in Mozambique.

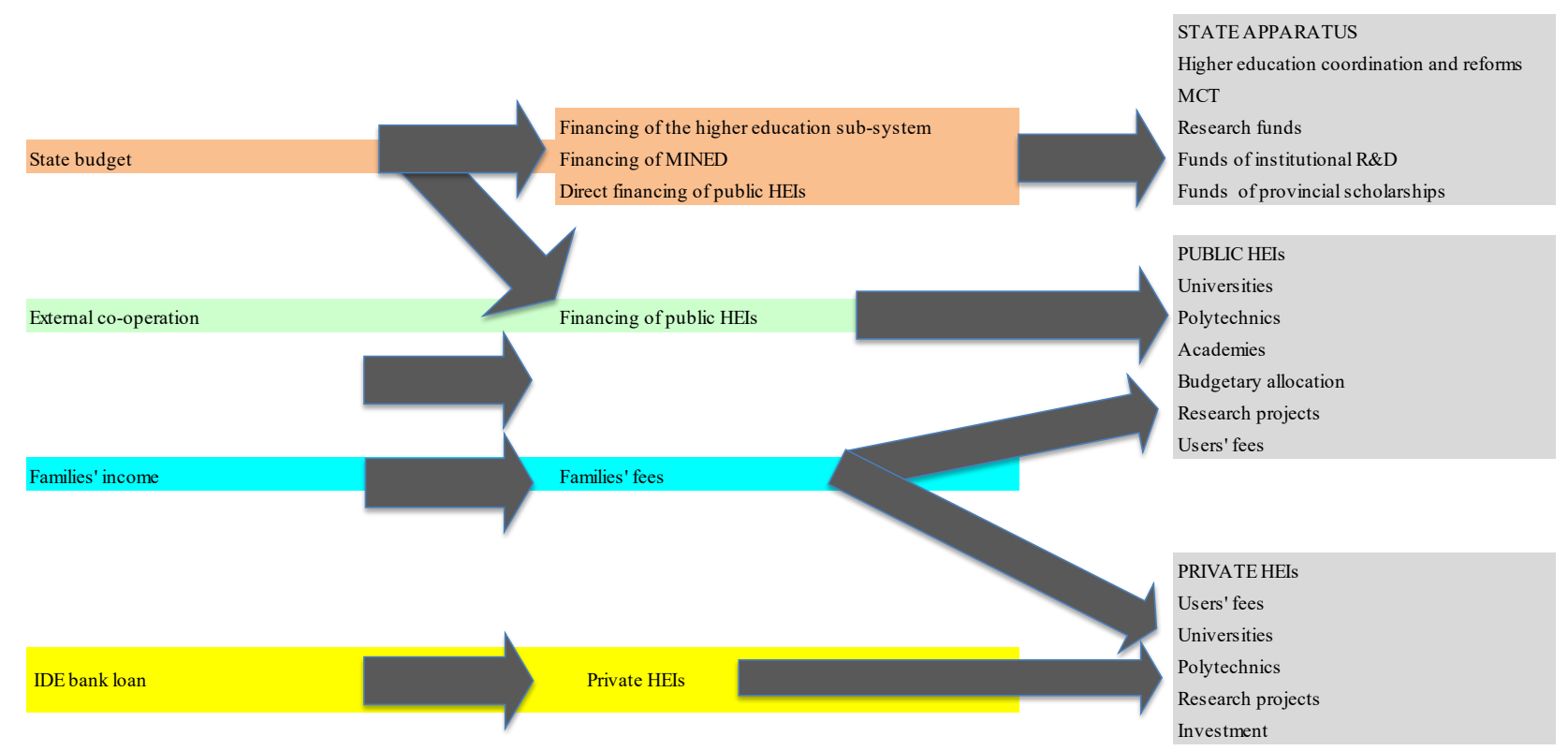

Figure 2: Current model of HE financing in Mozambique

Source: Ministry of Education (2012a, p. 39).

When this financing model is characterised according to the models of tuition policies in the HE financing, it fits into one of the cost-sharing policies considered to be a dual-track policy. This model is, according to Cerdeira (2008), characterised by a restricted public structure controlled by the government and a private sector that tends to grow more. Fees vary from one institution to the other, depending on their specificities in terms of the type of institution and education. In some institutions there are available places that are free of fees or subject to low fees, the number of available places is limited, and there is a selection of students for admission. The support that the government grants to students is always little and those that are not covered by the support have to pay tuition fees.

This model - which allows tuition fees to be paid in some institutions and not others, and in which there are night available places paid by some students that differ from day available places, as is the case in Mozambique - has been the subject of criticism in some studies, namely in terms of issues of social equity, despite the political acceptance they have had in Africa, insofar that

[...] it shows a different treatment of the two types of students (workers and non-workers), which calls into question the principles of social equity, by treating higher education candidates differently. Also, the after-work system can be questioned in terms of the access, as it reveals that people who are currently attending the night time have already been penalised at some point by the financing policy in force in the country, when they did not have the opportunity to attend higher education in their youth, which would be the right time to do so (Cerdeira et al., 2017, p. 59). 
In the same financing model, the public budget made available by the Mozambican government to HEIs has revealed, according to statistics, that direct financing, that is, from the State budget for public institutions (in education in general and in HE in particular) has increased year after year, as evidenced by the information in Graph 1 , which depicts the budgets for HE over the last four years.

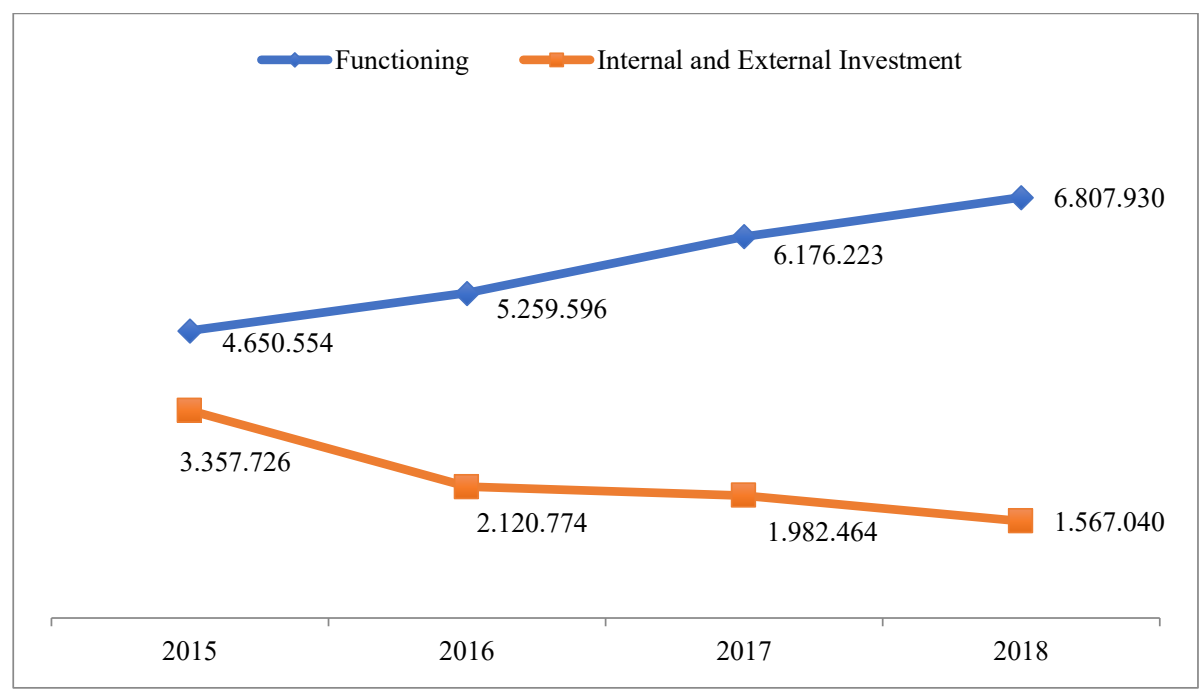

Graph 1: Evolution of the HE budget

Source: Based on information from the Ministry of Economy and Finance (2018).

This budgetary behaviour for HE, with a tendency to grow, has also been observed in several African countries, according to data from UNESCO-UIS.Stat (2019), Brossard and Foko (2007) and Pôle de Dakar (2008).

The amount made available to HEIs in terms of a share in the general state budget is about 2\% (Chilundo, 2010). It is expected that there will be some increase according to the 2012-2020 strategic plan, with the percentage of the budget allocated to the HEIs rising to $1.5 \%$ of the national GDP (Ministry of Education, 2012b).

However, despite the gradual increases in the budget channelled to the HEIs in general, the information provided in Graph 1 allows identifying a slight drop in both internal and external investments.

Furthermore, the impact of the HEI's annual budget growth has not been substantial, inasmuch that HEIs see, year after year, their budget proposals (which reflect their real needs) undergoing major cuts and they have to be content with the values that are granted in terms of finances.

This reality and practice are also common in many other African countries, as Teferra and Altbach (2003) note. That is why the scenarios in the budget projections for 2018, according to the strategic plan, indicated a budget of 9,000,000.00 MT against 6.176. 223.00 MT made available in the same year, as shown in Graph 1. The projected budget would allow, according to the same document, the availability of more places and could increase HE access.

Pillay (2011) justifies that the lack of coherence between the budget made available to HEIs in many African countries is due to the fact that HE is not the only priority social area in terms of investments, with others competing with it. However, this justification is not shared by Pôle de Dakar (2008), who believes that the reasons do not necessarily lie in the lack of priority that African governments ascribe to HE, but rather in the sharp increase in the number of students in this educational level, which justifies the decline in public funding per student.

However, Fonteyne and Jongbloed (2018) justify, for the case of the Mozambican reality, that the insufficiency of budgets allocated to the HEIs is due to the fact that negotiations for obtaining the budget are done directly between the HEIs and the Ministry of Economy and Finance (MEF) without a logical basis (for example, performance results from the HEIs themselves), which creates an information asymmetry. Furthermore, this situation puts the MEF in a disadvantageous negotiating position, which leads to the reference to historical budgets and expenses, given that, without a specific understanding of the HE sector, the MEF cannot truly assess budget requests according to the merits of each request. Moreover, the method that has been used is advantageous to older HEIs over newer ones.

Thus, whether for one reason or the other, the budget made available to HEIs becomes extremely inefficient, and, according to Pillay (2010), largely ad hoc. Also, it is not based on any attempt to develop a closer link between the planned at the level of HEIs and the budget made available. 
José Amilton Joaquim, and Luísa Cerdeira

This causes HEIs' managers, in the case of Mozambique, to be entrepreneurs and to seek other resources, as mentioned by the former Rector of University Lúrio in Mozambique, Prof. Francisco Noa, at the IV Congress on Cooperation and Quality Education (COOPEDU) in 2018, in his intervention titled "The challenges of higher education in Mozambique". Noa (2018) also stated that, due to budgetary cuts, public HEIs are forced to seek more and more private support partners, both internally and externally, and to encourage teachers to compete for institutional support projects to address financial gaps created by budget deficits. This situation tends to be much more difficult with the crisis that the country has been undergoing since 2015, with the disclosure of the so-called hidden or undeclared debts, which led the International Monetary Fund (IMF) to cut support for the general State budget that was granted to the parents. Furthermore, with the COVID-19 pandemic, the situation has become even more severe.

In the cost-sharing policy in force in Mozambique, the co-funding values that have been used as a basis to show the government expenses with students, according to Chilundo (2010), are around USD 2,500 per year per student enrolled in public HE. Also, students from the public system pay a low tuition fee - around USD 100 a year.

However, it is worth noting that these figures were calculated based on the expenses of the students at Eduardo Mondlane University in 2006, and until today they have been used as a basis for reflections on the cost-sharing proposals in Mozambique. This takes place albeit in 2011, as Fonteyne and Jongbloed (2018) state in the report on HE financing reform strategies in Mozambique, "the same amount was tested again in 2011 and, although it is strained as the fast growing number of students vastly outpaces the annual increases in state funded budgets for the public institutions, it can still be used as a reference value" (p. 81).

Yet, in a more attentive analysis of these values, it is clear that they do not include State institutions that charge students tuition, either in day or night study programmes. The $\$ 100$ mentioned above relate to a part of the costs considered by Whoodhall (2004) as direct costs, which are those of studies and not the total costs, which include the indirect living costs. As Vossensteyn (1999) explains,

The cost of education can be divided into study and living costs. Study costs refer to tuition fees and expenditure on study materials. Foregone earnings are left out of the comparisons, because they do not imply direct costs that students have to pay in order to study. Living costs can be further divided into nutrition, accommodation, travelling expenses and sundries like sport, entertainment, etc. (p. 162).

The empirical data of this study allow observing that, when all these (study and living) costs are taken into account, they far exceed the values mentioned above, as can be seen in Table 3. The two coupled expenses, for private education students, show an average of 136,593.33 MT and those for public education have an average of 81,542.12 MT.

These figures reveal that, despite the efforts that the State has been making, the real expenses of students who attend HE are possibly ignored in educational policies regarding the issue of their effective participation in HE funding.

In terms of indirect funding from social support for students, the Higher Education Law, in its article 5 on scholarships, states that "To allow higher education attendance and to mitigate the discriminatory effects resulting from economic and social inequalities, the State guarantees scholarships with pre-established dues and other forms of support" (Ministry of Education, 2012a, p. 27).

Nevertheless, the scholarship is the only means of social support granted to students in HE and it has been made available, on the one hand, directly to public HEIs and, on the other hand, as already mentioned, they are made available from the provincial scholarships managed by Instituto de Bolsas de Moçambique (Mozambique Scholarships Institution). Students from both public and private HEIs may have access to these scholarships.

Social support through scholarships is financed by the Mozambican State Budget and partner organisations.

\subsection{HIGHER EDUCATION STUDENTS' SOCIO-ECONOMIC FEATURES}

Regarding the results of the information collected through the questionnaire, the study allowed finding that the majority of students' households (45.9\% and 40.9\%) come from families with medium and low income, respectively (Graph 2). 
Financial Accessibility in Cost-Sharing Policies in Higher Education in Mozambique

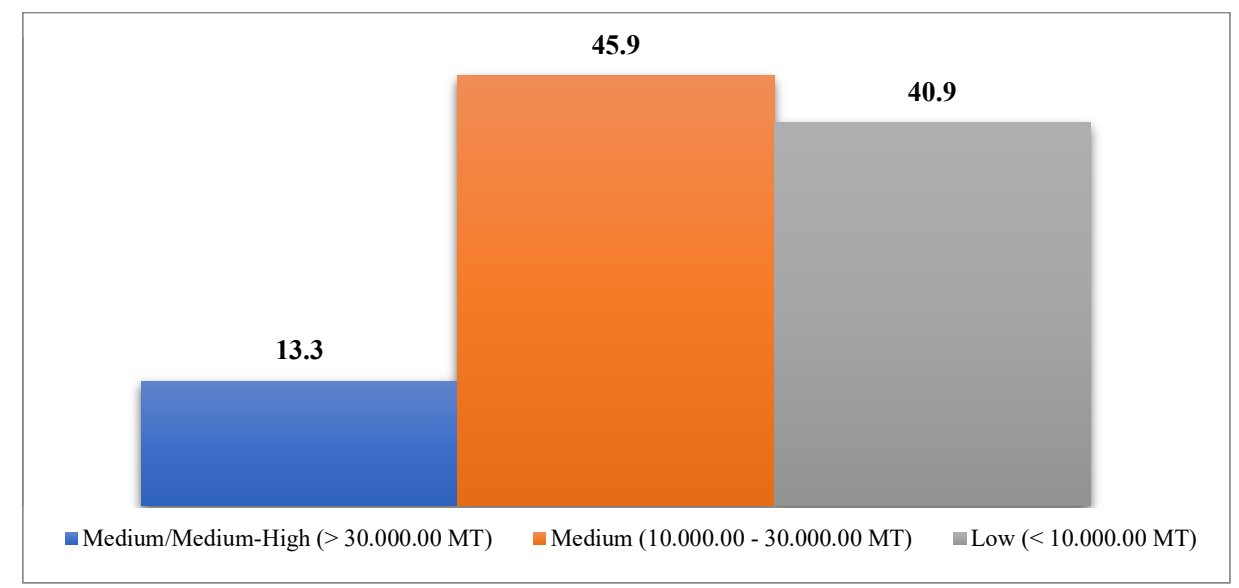

Graph 2: HE students' perception on the income of their household (\%)

Source: Produced by the authors.

The qualitative assessment that students make of their household income shows that the majority (39.7\%) perceive it as being enough to live on, but with difficulties, followed by students who stated that they live reasonably well with their household income (35.3\%) (Graph 3).

Source: Produced by the authors.

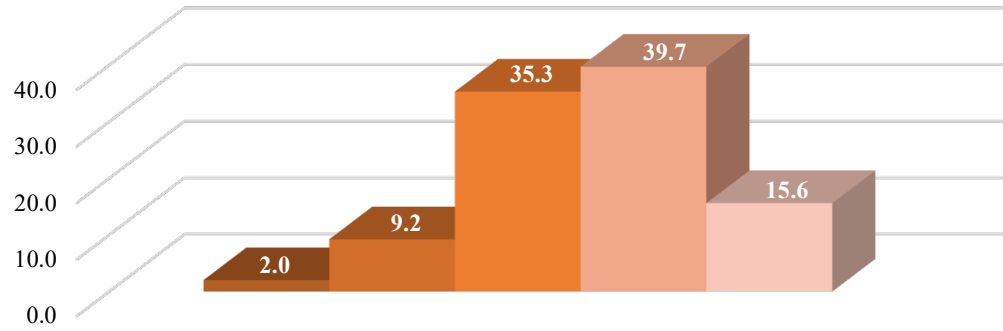

They are enough to live very well

They are enough to live well

They are enough to live reasonably well

They are enough to live but with difficulty

They are enough to survive with deprivation

Graph 3: Assessment of the household income (\%)

Graph 4 allows observing that the educational level of the highest number of students' parents is the lowest, with $64.2 \%$ of mothers holding an educational level up to the 9 th grade and $52.5 \%$ of parents holding this educational level (Graph 4).

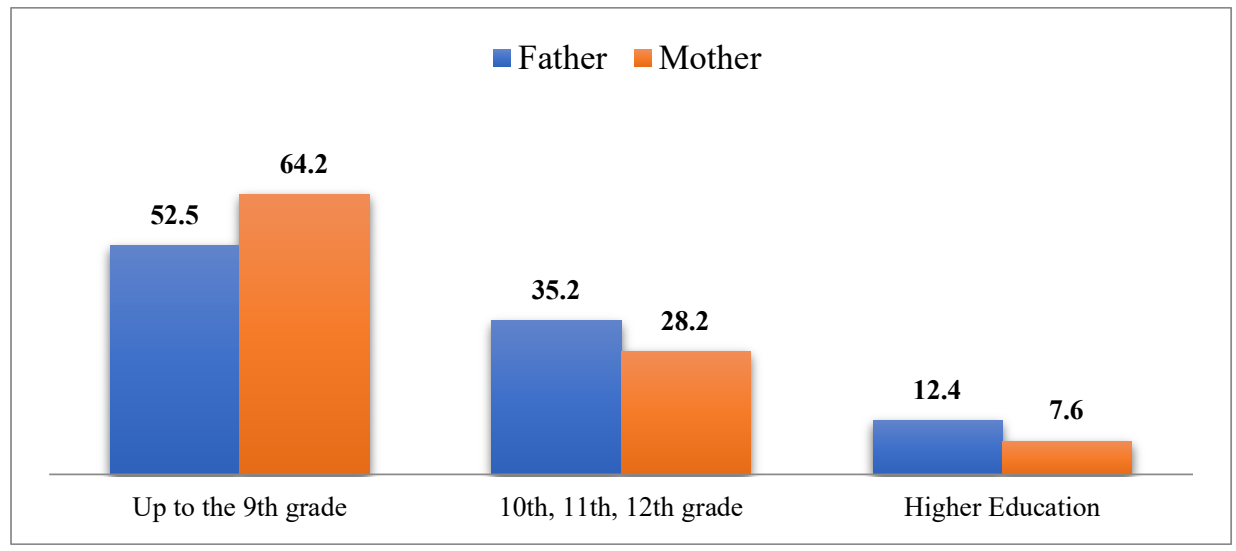

Source: Produced by the authors.

Graph 4: Educational level of HE students' parents 
The occupation of the students' parents who stood out the most is related to domestic activities. This is more evident in the case of students' mothers (39.6\%) vis-à-vis students' fathers $(11.0 \%)$. The parents of a significant group of students are also self-employed (24.4\% for fathers and 16.3\% for mothers) (Graph 5).

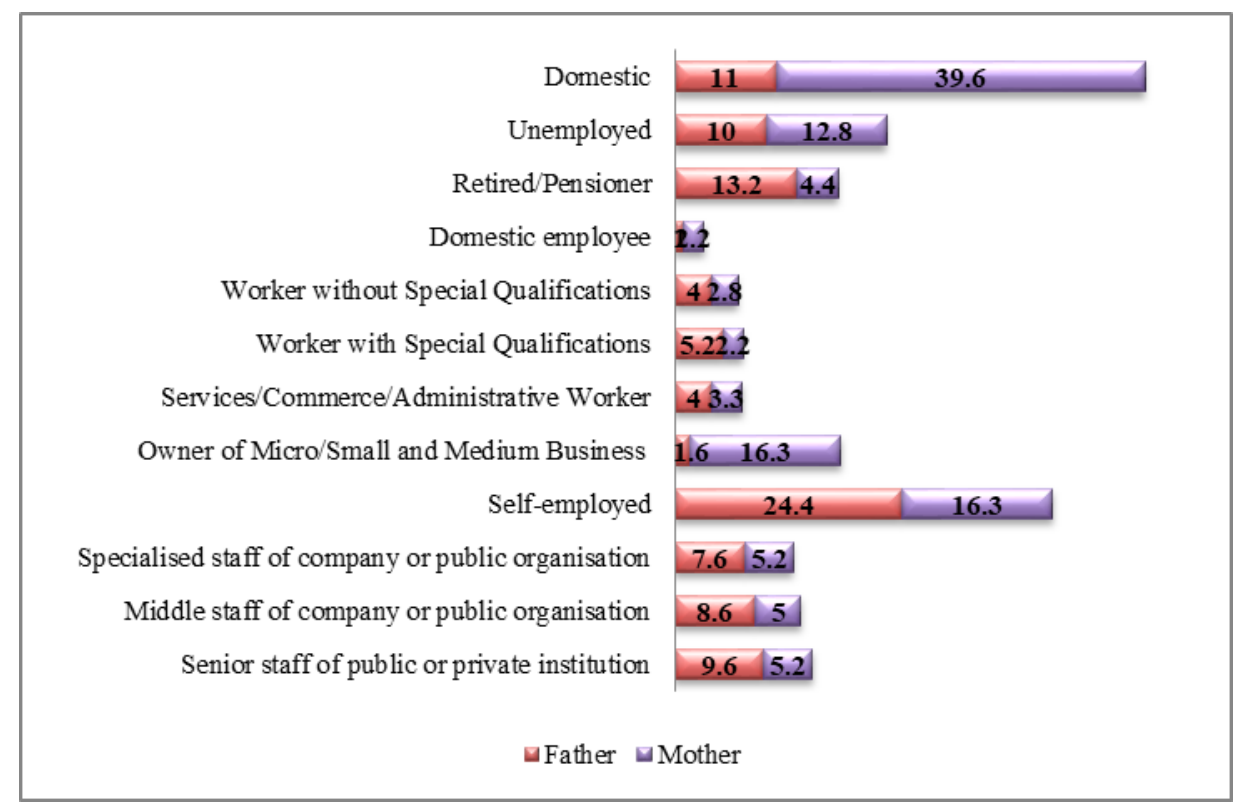

Source: Produced by the authors.

Graph 5: Occupational group of HE students' parents (\%)

\subsection{SOURCES OF INCOME AND COSTS OF HIGHER EDUCATION STUDENTS}

In addition to the information put forth in the previous sub-section, the study also allowed finding that the family is the biggest source of income for students, with an average annual contribution of 33,405.11 MT. This is followed by paid work, with an annual average of 20,302.64 MT, as shown in Graph 6.

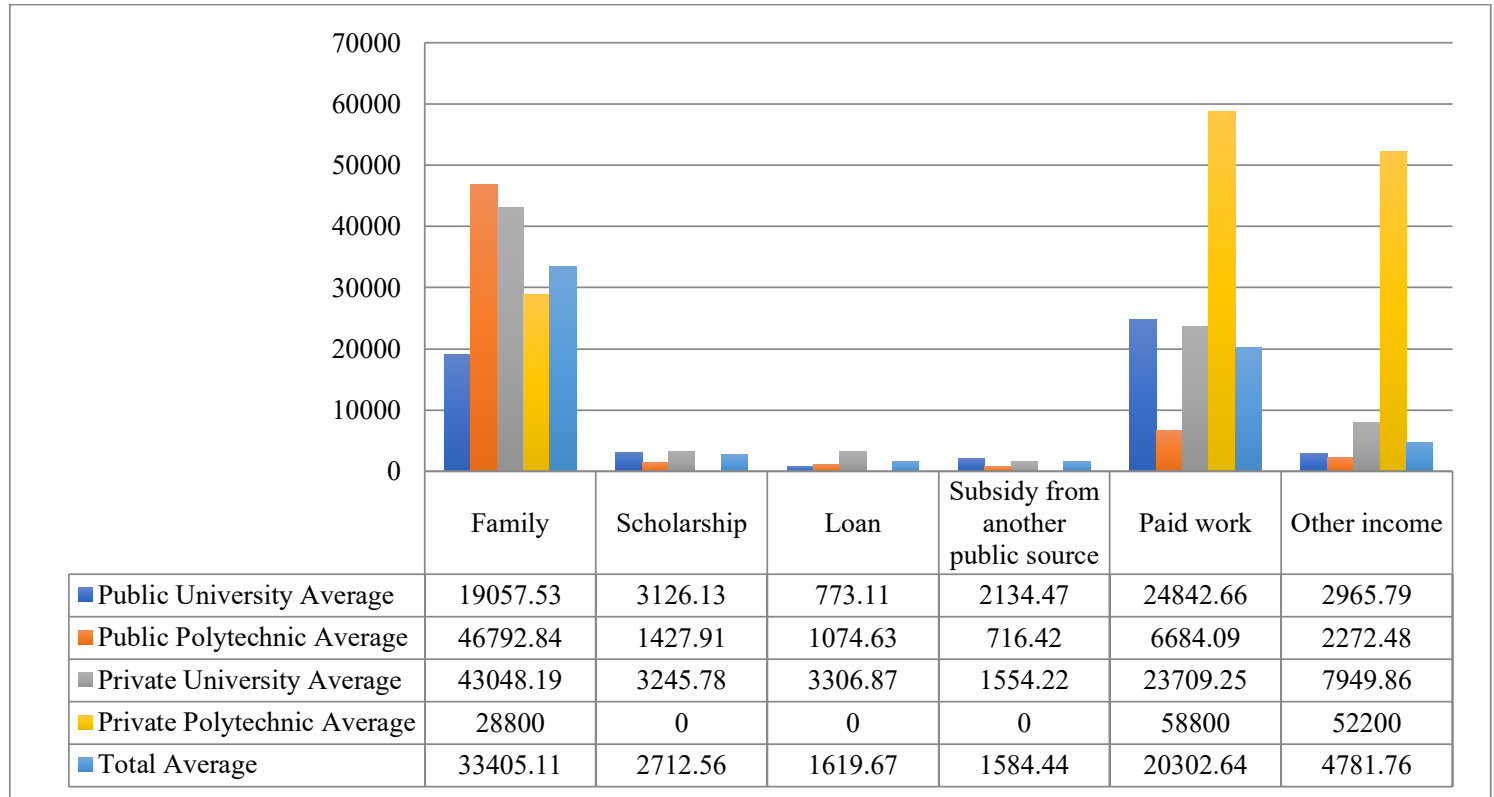

Graph 6: HE students' annual income of by type of income, sector and type of education (in MT) Source: Produced by the authors. 


\subsubsection{HIGHER EDUCATION STUDENTS' LIVING AND STUDY COSTS}

The results show that, in the relationship between the total expenses and the discriminated living and study costs, the students reveal to have higher expenses, on average, with food (24,333.71 MT), followed by the tuition or monthly fees $(20,882.61 \mathrm{MT})$, accommodation $(13,507.12 \mathrm{MT})$, personal expenses $(13,231.81 \mathrm{MT})$ and transportation (12,648.87 MT) (Graph 7).

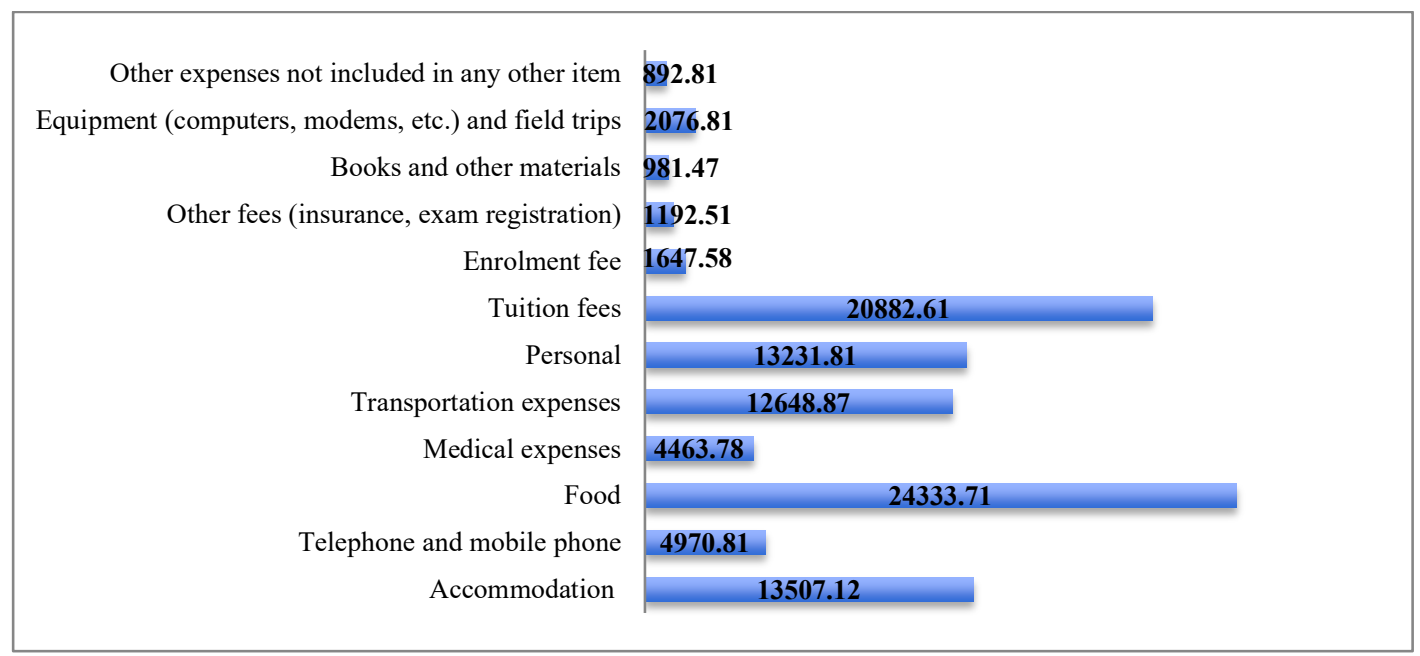

Graph 7: Provision of total expenses for HE students by type of cost (in MT)

Source: Produced by the authors.

When we separate the same costs (living and study costs) according to the sector and type of education, the analysis reveals that, concerning living costs, students in private HE have higher expenses annually vis-a-vis students in public education. Both Private Polytechnic and Private University students have annual expenses above 100,000 MT per year, whereas public HEIs students' have living expenses are below 70,000 MT per year (Table 1).

Table 1: Annual current expenditure by sector and type of education (in MT)

\begin{tabular}{|c|c|}
\hline & Average \\
\hline Public University & 67.445 .46 \\
\hline Public Polytechnic & 56.773 .16 \\
\hline Private University & 102.549 .4 \\
\hline Private Polytechnic & 106.080 .00 \\
\hline Total & 75.946 .09 \\
\hline
\end{tabular}

Source: Produced by the authors.

Students who attend Private Polytechnic education have, on average, higher expenses in terms of annual education expenses $(66,144.00$ MT). They are followed by students who attend Private University education (50,102.89 MT), Public Polytechnic education (21,993.40 MT) and, lastly, Public University education $(15,534.04$ MT).

It is, thus, possible to conclude that students who attend both public and private Polytechnic education have higher annual expenses with education in comparison with students who attend university education (Table 2).

Table 2: Annual education expenses by sector and type of education (in MT)

\begin{tabular}{|c|c|}
\hline \multirow{2}{*}{} & Total Education expenses \\
\cline { 2 - 2 } & Average \\
\hline Public University & $15.534 .04 \mathrm{MT}$ \\
\hline Public Polytechnic & $21.993 .40 \mathrm{MT}$ \\
\hline Private University & $50.102 .89 \mathrm{MT}$ \\
\hline Private Polytechnic & $66.144 .00 \mathrm{MT}$ \\
\hline
\end{tabular}


José Amilton Joaquim, and Luísa Cerdeira

Source: Produced by the authors.

\begin{tabular}{l|l} 
Total & $28.232 .25 \mathrm{MT}$ \\
\hline
\end{tabular}

When coupled with the students' costs, both with study or living expenses, as shown in Table 3, the data show that, for students attending private education, the total expenditure is higher $(136,593.33 \mathrm{MT})$ than the total expenditure for students attending public education (81,542.12 MT). The average total amount for study and living expenses is over 100,000.00 MT per year.

Table 3: Total annual expenditure (study and living) by type of education (in MT)

\begin{tabular}{|c|c|}
\hline \multirow{2}{*}{} & Total annual expenditure (Current + Education) \\
\cline { 2 - 2 } & Average \\
\hline Public & 81.542 .12 \\
\hline Private & 136.593 .33 \\
\hline Total & 100.939 .36 \\
\hline
\end{tabular}

Source: Produced by the authors.

\subsection{HIGHER EDUCATION STUDENTS' FINANCIAL ACCESSIBILITY}

Cerdeira (2008) argues that accessibility per se is not enough to provide the necessary information about the possible financial barriers that students face. For this purpose, there is the need to take into account the financial accessibility, which can indicate the circumstances and necessary resources that students own to pay for their studies.

Considering the economic indicator for this purpose available in Mozambique, this study used a comparison of both the students' annual living and study costs with the value of GDP per capita.

Mozambique's GDP per capita corresponds to 31,553.00 MT for 2018, according to information from Trading Economics-Mozambique (2019).

Thus, to better understand the students' economic accessibility to HE, two scenarios will be presented. The first will compare the students' costs with GDP per capita without deducting the amount of social support granted to students. The second scenario deducts the value of the annual scholarship, as recommended by Hill et al. (2004).

When comparing students' expenditure with the country's GDP per capita, as shown in Table 4 and corresponding to the first scenario, it is possible to notice that the students' costs in HE are much higher than the national income in question.

Table 4: HE students' living and study costs compared to GDP per capita

\begin{tabular}{|c|c|c|}
\hline & Study Costs & Living Costs \\
\hline Average of costs & 28.232 .25 & 75.946 .09 \\
\hline GDP per capita & 31.553 .00 & 31.553 .00 \\
\hline
\end{tabular}

Source: Produced by the authors.

This result reveals that there is a huge cost for students and their families to access and remain in HE. This clearly shows, as mentioned by Johnstone (2001), that the term cost-sharing, as it has been used, regards the shift of, at least, part of the higher educational burden from the government or taxpayers to parents and students.

Moreover, given that HE, as Nicolas Bar (2005) reminds us, is a fundamental asset for the development of a country, it is also a determining factor of an individual's potential regardless of his/her social condition. In this case, that is being threatened in favour of social groups that can remain in HE without any problem in view of the costs presented.

Before putting forward the second scenario, we present the data referring to the monthly scholarship values received by students.

Most scholarship students (see Graph 8) reported that they receive a subsidy from the highest monthly scholarship, above 3,000 MT (33.51\%), followed by students who receive a scholarship in the amount between $2,001.00$ and 3,000.00 MT (17.26\%). 
The lowest grants, in the amount of $750.00 \mathrm{MT}$, are earned by few students (4.6\%), whereas the amount between 751.00 and $1,250.00$ MT is earned by $2.3 \%$ of the students surveyed.

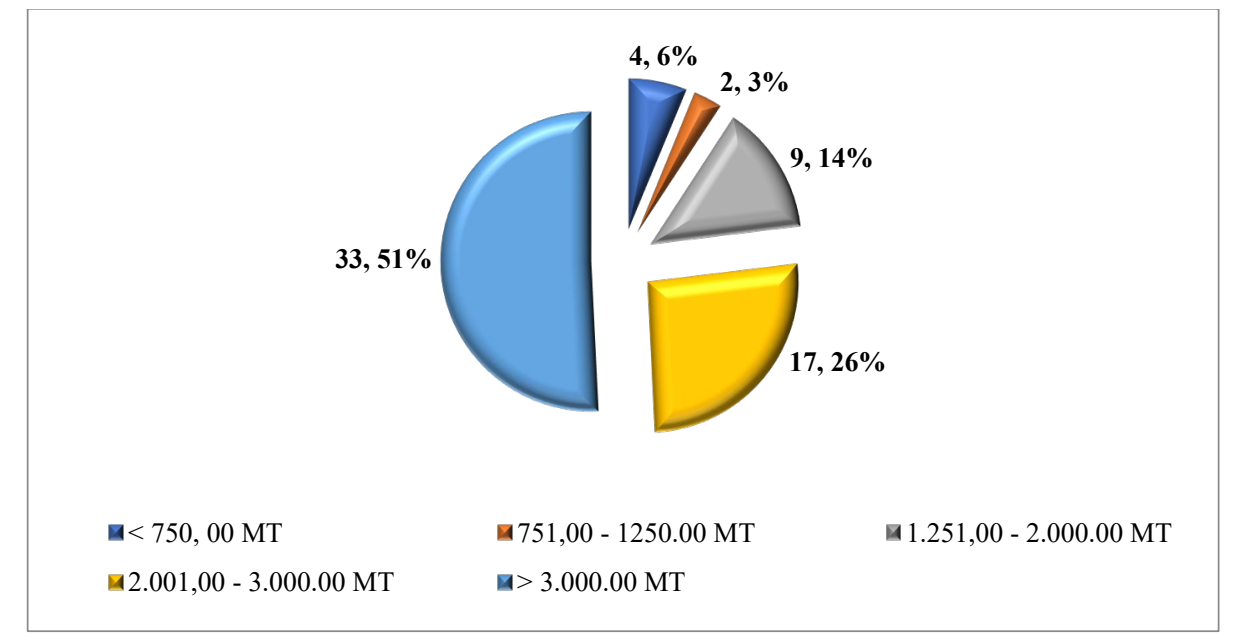

Graph 8: Monthly scholarship value of HE students (in number and \%)

Source: Produced by the authors.

Regarding the second scenario, Graph 9 shows that, even with the deduction of the amount of the annual grant from the scholarship, having as reference the highest subsidy indicated by the students, that is, 3,000.00 MT per month, the costs incurred by students, both with living and study expenditure, and compared with the indicator of the national income of the population, students' costs continue to be twice as high as GDP per capita.

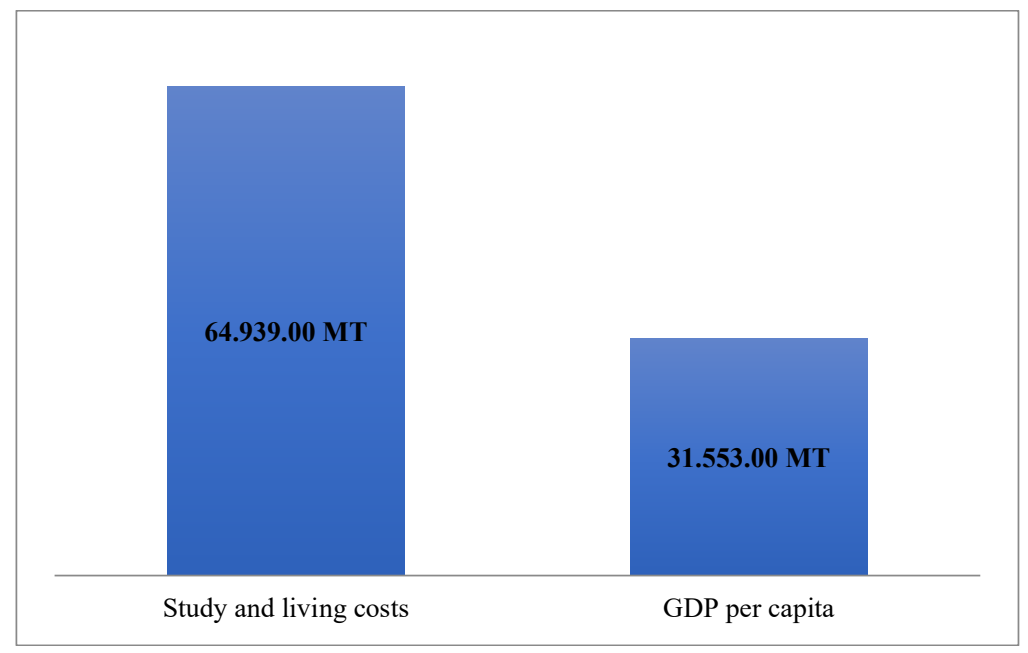

Graph 9: HE students' costs (Study and living costs) minus the scholarship value versus 2018 GDP per capita Source: Produced by the authors.

The analysis of the data that characterise the conditions of most students' households depicts a clear situation of financial barrier and, consequently, the financial effort that students and their families are making to attend and remain in HE. Moreover, there is the aggravating factor of a non-efficient mechanism for awarding scholarships, as the current system is not organised in a way that stratifies students in terms of their real social condition.

Fonteyne and Jongbloed (2018) report that there has already been an attempt to incorporate a software application to stratify candidates according to their socio-economic status. This was not possible after a small-scale pilot test, carried out by the Institute of Scholarships, which launched a nationwide race with all $12^{\text {th }}$-grade students who wished to pursue HE. The results were mixed and many questions remained to be solved, especially how to 
overcome resistance to fiscal transparency and the record of candidates with the Unique Tax Identification Number (NUIT) ${ }^{1}$.

Moreover, the lack of diversification of other social supports for students is another obstacle to access, insofar that the scholarship is the only means of support for students in Mozambique.

There is the need to clarify that what is at stake is no objection to the diversification of funding sources or the cost-sharing policies per se. However, the objection is to the fact that, according to Cabrito (2004), the State is reducing its financial responsibilities from deficit budgets for HEIs, to the detriment of students and families, especially those most deprived of conditions for accessing $\mathrm{HE}$ and that end up being the most penalised.

\section{CONCLUSION}

In conclusion, the results from this study allow asserting that there is still a need to reflect on the cost-sharing policies in force in Mozambique, given that they fall short of what is required for not yet allowing accessibility and effective equity for most Mozambican families. It is sought that families not only enrol their children in HE but also have the financial capacity to keep them in both public and private HE. Otherwise, the country runs the risk of feeding a HE system that is confused with a socially unfair elitist system for creating, a priori, segregation of students according to their social and economic conditions. Also, this status quo is displacing the creation and transition of knowledge from the social sphere to the production one and, in doing so, the educational system runs the risk of perpetuating social reproduction within disadvantaged families, considering what the students mentioned regarding the educational qualifications of their parents or guardians, who mostly did not have the opportunity to attend secondary school, let alone HE.

This reality must have contributed, to some extent, to the fact that the most of the professions of the students' parents do not reveal a framework in terms of opportunities for socially well-paid activities; quite the opposite, many of them are domestic workers and self-employed, as the study also revealed.

These scenarios can be safeguarded by improving the financing of HEIs because, although the budgets granted to public HEIs tend to grow year after year, they are more political than technical as they do not satisfy the real needs of HEIs.

The family is the most important source of income for students vis-a-vis other sources, such as paid work and social support from scholarships. There is an urgent need to rethink HE financing policies so that students/families' socio-economic conditions are taken into account. There is also the need to reassess the students' real study and living costs while attending HE in the country. The costs that have been officially considered and that have served as models for the proposals and perspectives for a new financing model for HEIs, in addition to not meeting the students' real expenditure, set aside the living costs during the period in which the student attends HE.

Better economic accessibility for students also entails enhancing the efficiency of the system of awarding scholarships, so that it serves disadvantaged students. There is the need to broaden the range of social support so that it will allow many more underprivileged Mozambican families to be covered and have the possibility, not only to access HE but also to remain until they conclude their studies at this educational level.

It is paramount to ensure a continuous and sustainable HE development in Mozambique, where this educational level, taking into account its responsibility towards society, will contribute, not only to social injustice but to the effective inclusion of all social strata. This will prevent wasting the talent of many young people who aspire one day to enrol in HE to have a chance to improve their lives and that of their families and to be able to make a valuable contribution to the highly needed development of the country.

\section{SOURCES OF FUNDING}

This research received no specific grant from any funding agency in the public, commercial, or not-for-profit sectors.

${ }^{1}$ NUIT is a registration number that must be used by all natural or legal persons and similar entities, even if they have tax-free income, and it must be used in all taxes, including customs. 
Financial Accessibility in Cost-Sharing Policies in Higher Education in Mozambique

\section{CONFLICT OF INTEREST}

The author have declared that no competing interests exist.

\section{ACKNOWLEDGMENT}

None.

\section{REFERENCES}

[1] Barr, N. (2005). Financing higher education: Lessons from the UK debate. LSE Research Online, (June), 371381. Retrieved from http://eprints.lse.ac.uk/287/1/Barr_2003_PQ030430.pdf

[2] Barr, N. (2007). Financing higher education: Lessons from developed economies, options for developing economies. In Regional bank conference on development economics (p. 41). Beijing: World Bank. Retrieved from http://citeseerx.ist.psu.edu/viewdoc/download?doi=10.1.1.606.9214\&rep=rep1\&type

[3] Backer, G. S. (1993). Human capital: Theoretical and empirical analysis with special reference to education, 3rd ed. New York: The University of Chicago.

[4] Brossard, M., \& Foko, B. (2007). Coûts et financement de l'enseignement supérieur en Afrique francophone [Higher education costs and financing in French-speaking Africa]. Washigton, D.C: Banque Mondiale/UNESCO-BREDA.

[5] Cabrito, B. G. (2004). O financiamento do ensino superior em Portugal: Entre o Estado e o mercado [Financing higher education in Portugal: Between the State and the market]. Educação \& Sociedade, 25(88), 977-996. https://doi.org/10.1590/S0101-73302004000300016

[6] Cerdeira, M. L. (2008). O Financiamento do Ensino Superior Português. A partilha de custos [The financing of Portuguese higher education. Cost-sharing]. University of Lisbon, Faculty of Psychology and Educational $\begin{array}{lllll}\text { Sciences. } & \text { Faculdade } & \text { de } & \text { Lisboa. } & \text { Retrieved }\end{array}$ http://repositorio.ul.pt/bitstream/10451/973/1/17269_TeseLuisaCerdeira2Abril2009

[7] Cerdeira, L., Cabrito, B. (Orgs.), Patrocínio, T., Machado, M. L., \& Brites, T. (2014). Custos dos estudantes do ensino superior Português: Relatório CESTES 1. Para compreensão da condição social e económica dos estudantes do ensino superior [Costs of Portuguese higher education students: CESTES Report 1. Understanding the social and economic condition of higher education students]. Lisboa: Educa.

[8] Cerdeira, L. (Coord.), Machado-Taylor, M. L., Cabrito, B., Brites, R., Patrocínio, T., \& Manso, M. (2017). Estudo sobre os custos e o financiamento do ensino superior em Angola [Study on higher education costs and financing in Angola]. Luanda: CESO Development Consultants and African Development Bank.

[9] Chevaillier, T., \& Eicher, J.-C. (2002). Higher education funding: A decade of changes. Higher Education in Europe, 27(1-2), 89-99. https://doi.org/10.1080/0379772022000003242

[10] Chevaillier, T., \& Paul, J.-J. (2008). Accessibility and equity in a state-funded system of higher education: The French case. In P. N. Teixeira, D. B. Johnston, M. J. Rosa, \& Vessensteyn, H. (Eds.), Cost-sharing and accessibility in higher education: A fairer deal? (pp. 295-317). Dordrecht: Springer.

[11] Chilundo, A. (2010). Mozambique. In P. Pundy (Ed.), Higher education financing in East and Southern Africa (pp. 103-121). Somerset West: African Minds.

[12] Fonteyne, B., \& Jongbloed, B. W. A. (2018). Implementing the strategy for financial reform of higher education in Mozambique (EFES). Enschede: CHEPS - Center for Higher Education Policy Studies.

[13] Eicher, J. C. (1998). The costs and financing of higher education in Europe. European Journal of Education, 33(1), 31-39. Retrieved from www.jstor.org/stable/1503782

[14] Hauptman, A. (2007). Higher education finance: Trends and issues. In J. J. F. Forest, \& P. G. Altbach (Eds.), International handbook of higher education (pp. 83-106). Dordrecht: Springer. https://doi.org/10.1007/9781-4020-4012-2_6

[15] Hill, C., Winston, G., \& Boyd, S. (2004). Affordability: Family incomes and net prices at highly selective private colleges and universities. Williams Project on the Economics of Higher Education. Retrieved from http://www.williams.edu/wpehe 
José Amilton Joaquim, and Luísa Cerdeira

[16] Johnstone, D. B. (2001). Student loans in international perspective: Promises and failures, myths and partial truths. Retrieved from http://ahero.uwc.ac.za/index.php?module=cshe\&action=downloadfile\&fileid=81806115511848321656696 $\% 0 \mathrm{D} \% 0 \mathrm{D}$

[17] Johnstone, D. B. (2004). The economics and politics of cost sharing in higher education: Comparative perspectives. Economics of Education Review, 23(4), 403-410. https://doi.org/10.1016/j.econedurev.2003.09.004

[18] Johnstone, D. B. (2005). Higher educational accessibility and financial viability: The role of student loans. Barcelona. Retrieved from http://gse.buffalo.edu/org/inthigheredfinance/

[19] Johnstone, D. B. (2010). Financing higher education: Worldwide perspectives and policy options. Retrieved from http://gse.buffalo.edu/org/inthigheredfinance/

[20] Johnstone (2014). Financing Higher Education: Worldwide Perspectives and Policy Options. Retrieved from http://gse.buffalo.edu/org/inthigheredfinance/

[21] Law 4/83, March 23, 1983. National Education System.

[22] Marcucci, P. N., \& Johnstone, D. B. (2007). Tuition fee policies in a comparative perspective: Theoretical and political rationales. Journal of Higher Education Policy and Management, 29(1), 25-40. http://doi.org/10.1080/13600800600980015

[23] Ministry of Economy and Finance (2018). National Directorate of Planning and Budget. Maputo: Ministry of Economy and Finance.

[24] Ministry of Education (2012a). Colectânea de legislação do ensino superior [Collection of higher education legislation]. Maputo: Directorate for Higher Education Coordination.

[25] Ministry of Education (2012b). Plano estratégico do ensino superior 2012-2020 [Strategic plan for higher education 2012-2020]. Maputo: Ministry of Education.

[26] National Directorate of Higher Education (2018). Importância da avaliação para a garantia de qualidade: 0 caso de Moçambique [The importance of assessment for quality assurance: The case of Mozambique]. Topic presented at the Forges Pre-Conference in November 2018, by the National Director of Higher Education in Mozambique. Ministry of Science and Technology, Higher Education and Professional Training.

[27] Noa, F. (2018). Os desafios do ensino superior em Moçambique [The challenges of higher education in Mozambique]. Paper presented at the IV Congresso sobre a Cooperação e Educação de Qualidade (COOPEDU) [IV Congress on Cooperation and Quality Education (COOPEDU)]. Lisboa: COOPEDU.

[28] OECD (2017). Education at a glance 2017. OECD indicators. Paris: OECD. http://dx.doi.org/10.1787/eag2017-en

[29] Ogachi, I. O. (2011). Neo-liberalism and the subversion of academic freedom from within: Money, corporate cultures and 'captured' intellectuals in African public universities. JHEA/RESA, 9(1 \& 2), 25-47.

[30] Pillay, P. (2010). Higher education financing in East and Southern Africa. Somerset West: Centre for Higher

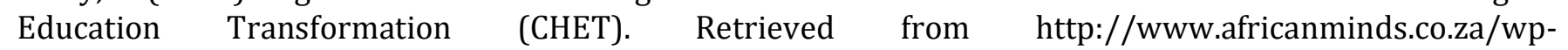
content/uploads/2012/06/13407160372101493429

[31] Pillay, P. (2011). Higher education and economic development. Literature review. Wynberg: Centre for Higher Education Transformation (CHET). Retrieved from http://www.africanminds.co.za/wpcontent/uploads/2012/06/13407160372101493429.pdf

[32] Pôle de Dakar (2008). Reformes de l'enseignement superieur en Afrique: Elements de cadrage [Higher education reforms in Africa: Framework elements]. Paris: Breda/UNESCO.

[33] Schultz, T. W. (1961). Investment in human capital. The American Economic Review, 51(1), 1-17. Retrieved from www.jstor.org/stable/1818907

[34] Teferra, D., \& Altbach, P. G. (2003). African higher education: Challenges for the 21st century. Higher Education 47, 21-50. https://doi.org/10.1023/B:HIGH.0000009822.49980.30

[35] Tekleselassie, A. A., \& Johnstone, D. B. (2004). Means testing: The dilemma of targeting subsidies in African higher education. Journal of Higher Education in Africa / Revue de L'enseignement Supérieur en Afrique, 2(2), 19. Retrieved from https://www.semanticscholar.org/paper/Means-Testing\%3A-The-Dilemma-ofTargeting-Subsidies-Tekleselassie-Johnstone/dc7878ce04042d07d35f66c8ab0dca8f09d2bcda

[36] Trading Economics (2019). Mozambique - Economic Indicators. Retrieved from https://tradingeconomics.com/mozambique/indicators 
[37] UNESCO-UIS Stat. (2019). Government expenditure on education as a percentage of GDP. Retrieved from http://data.uis.unesco.org/?queryid=142

[38] Vossensteyn, J. J. (1999). Where in Europe would people like to study? The affordability of higher education in nine Western European countries. Higher Education, 37, 159-176. https://doi.org/10.1023/A:1003595031626

[39] Vossensteyn, H., \& Jong, U. (2006). Student financing in the Netherlands: A behavioural economic perspective. In P. N. Teixeira, B. Johnstone, M. J. Rosa, \& H. Vossensteijn (Eds.), Cost-sharing and accessibility in higher education: A fairer deal? (pp. 213-239). Dordrecht: Springer. https://doi.org/10.1007/1-4020-4660-X_9

[40] Vossensteyn, H. (2009). Challenges in student financing: State financial support to students: A worldwide perspective. Higher Education in Europe, 34(2), 171-187. https://doi.org/10.1080/03797720902867294

[41] Woodhall, M. (2004). Student loans: Potential, problems, and lessons from international experience. JHEA/RESA, 2(2), 37-51. Retrieved from https://www.codesria.org/IMG/pdf/3-woodhall

[42] Woodhall, M. (2007). Funding higher education: The contribution of economic thinking to debate and policy development. Washington, D.C.: World Bank. Retrieved from http://siteresources.worldbank.org/EDUCATION/Resources/278200-1099079877269/5476641099079956815/Funding_HigherEd_wps8

[43] Zeleza, P. T. (2016). The transformation of global higher education, 1945-2015. New York: Palgrave Macmillan. 